\title{
Reproductive Biology of Ethmalosa fimbriata (Bowdich) in Senegalese Coastal Waters
}

\author{
Alioune FAYE \\ Institut Universitaire de Pêche et d'Aquaculture (IUPA), Université Cheikh Anta Diop \\ UCAD II bâtiment pédagogique/Rez de chaussée, BP: 5005 DAKAR. \\ E-mail: fayealioune@ hotmail.be
}

\begin{abstract}
Alassane SARR
Institut Universitaire de Pêche et d'Aquaculture (IUPA), Université Cheikh Anta Diop UCAD II bâtiment pédagogique/Rez de chaussée, BP: 5005 DAKAR
\end{abstract}

\section{Modou THIAW}

Centre de Recherche Océanographique Dakar Thiaroye (CROTD)

\section{Ismaila NDIAYE}

Institut Universitaire de Pêche et d'Aquaculture (IUPA), Université Cheikh Anta Diop UCAD II bâtiment pédagogique/Rez de chaussée, BP: 5005 DAKAR

\section{Kamarel BA}

Institut Universitaire de Pêche et d'Aquaculture (IUPA), Université Cheikh Anta Diop

UCAD II bâtiment pédagogique/Rez de chaussée, BP: 5005 DAKAR

\section{Jean FALL (Corresponding author)}

Institut Universitaire de Pêche et d'Aquaculture (IUPA), Université Cheikh Anta Diop

UCAD II bâtiment pédagogique/Rez de chaussée, BP: 5005 DAKAR

Tel: 221-77-956-4339_E-mail: kagoshima77@yahoo.com 
Malick Diouf

Institut Universitaire de Pêche et d'Aquaculture (IUPA), Université Cheikh Anta Diop

UCAD II bâtiment pédagogique/Rez de chaussée, BP: 5005 DAKAR

\title{
Omar Thiom Thiaw
}

Institut Universitaire de Pêche et d'Aquaculture (IUPA), Université Cheikh Anta Diop

UCAD II bâtiment pédagogique/Rez de chaussée, BP: 5005 DAKAR

\section{Najih LAZAR}

Research Associate III, department of Fisheries, University of Rhode Island East Farm Kingston

Received: November 22, 2013 Accepted: December 7, 2013

doi:10.5296/jbls.v5i1.4903ＵRL: http://dx.doi.org/10.5296/jbls.v5i1.4903

\begin{abstract}
Ethmalosa fimbriata is a very abundant species in marine and estuarine waters of Senegal. It is caught only by artisanal fisheries. Some aspects of its reproduction are studied in order to provide some contribution to a rational and sustainable management of the fishery. To evaluate the reproduction of Ethmalosa fimbriata, the sex ratio, the size at first maturity, the evolution of sexual maturity stages and the gonadosomatic index (GSI) were used. The results show that the sex ratio is $46 \%$ of males and $54 \%$ of females in the estuary while at sea it is $42 \%$ of males against $58 \%$ of females. Size at first maturity is $16.2 \mathrm{~cm}$ for males and $17.5 \mathrm{~cm}$ for females in the estuary, while at sea these sizes are respectively equal to 17.2 and $18.7 \mathrm{~cm}$ for females and males. The main breeding periods are during the cold season in the estuary and the hot season at sea. Ethmalosa fimbriata is a species with small eggs and high fecundity. The absolute and relative fecundity are higher in the estuary than at sea.
\end{abstract}

Keywords: Ethmalosa fimbriata, Estuary, Sea, Reproduction, Fecundity.

\section{Introduction}

Most of the landings of the artisanal fisheries of Senegal consist of small pelagic. Ethmalosa fimbriata is one of the most important small pelagic inhabiting coastal and estuarine waters of Senegal. In 2009, catches of Ethmalosa fimbriata were estimated at 6000 tons, about 2 percent of the total catch of small pelagic species in Senegal (FAO, 2011). The report of the Working 


\section{Macrothink}

Group of the FAO (2010) on small pelagic in the region of North-West Africa, considers that the Bonga stock in this region is fully exploited. Catches of Bonga decreased from 13000 tons in 2003 to less than 6000 tons in 2006, a decrease of over 45\%. The Bonga catches in The Gambia and Senegal show a downward trend since 2003, with some fluctuations. In the Senegambian region, Bonga stock is overexploited. This operating level concern mainly small sizes (FAO, 2011). This overexploitation is the result of consuming plenty of bonga in Senegal, its export in the sub-region, but also a lack of a management of its fishery.

Biology of Ethmalosa fimbriata has been the subject of previous studies in Senegal by Blanc (1951) and Boely Elwertowski (1970); Scheffers et al. (1972); Scheffers (1973); Conand and Scheffers (1976), Diouf (1996); Panfili et al. (2004). Its biology has also been studied in other West African countries (Gambia, Ivory Coast, Nigeria, Sierra Leone, Cameroon, Ghana, etc.). In Senegal, the first biological data back from the 1950s and 1970s. The most recent study in Senegal on this species was made by Panfili et al. (2004) in the Saloum estuary. It appears from this literature review that available biological data on Ethmalosa fimbriata still remain insufficient and old for fishing in Senegal.

It was recommended by the COPACE (2012) a biological sample of Ethmalosa fimbriata for different fisheries of Senegal to estimate biological parameters. The objective of this study is to contribute to the updating of biological data of Ethmalosa fimbriata by the studying its reproduction for better monitoring and good management of its fishery.

\section{Materials and Methods}

\subsection{Sampling Sites}

Sampling is performed in major centers landings in the region of Thies: Mbour $\left(14^{\circ} 24^{\prime} 42^{\prime \prime} \mathrm{N}\right.$ and $16^{\circ} 57^{\prime} 57^{\prime \prime} \mathrm{W}$ ) and Joal (14 $10^{\circ} 00^{\prime \prime} \mathrm{N}$ and $\left.16^{\circ} 49^{\prime} 59^{\prime \prime} \mathrm{W}\right)$, and Fatick Saloum Island (Foundiougne: $14^{\circ} 07^{\prime} 59^{\prime \prime} \mathrm{N}$ and $16^{\circ} 28^{\prime} 00^{\prime \prime} \mathrm{W}$ ). 


\section{MInstitute Macrothink $^{\text {Int }}$}

Journal of Biology and Life Science ISSN 2157-6076 2014, Vol. 5, No. 1

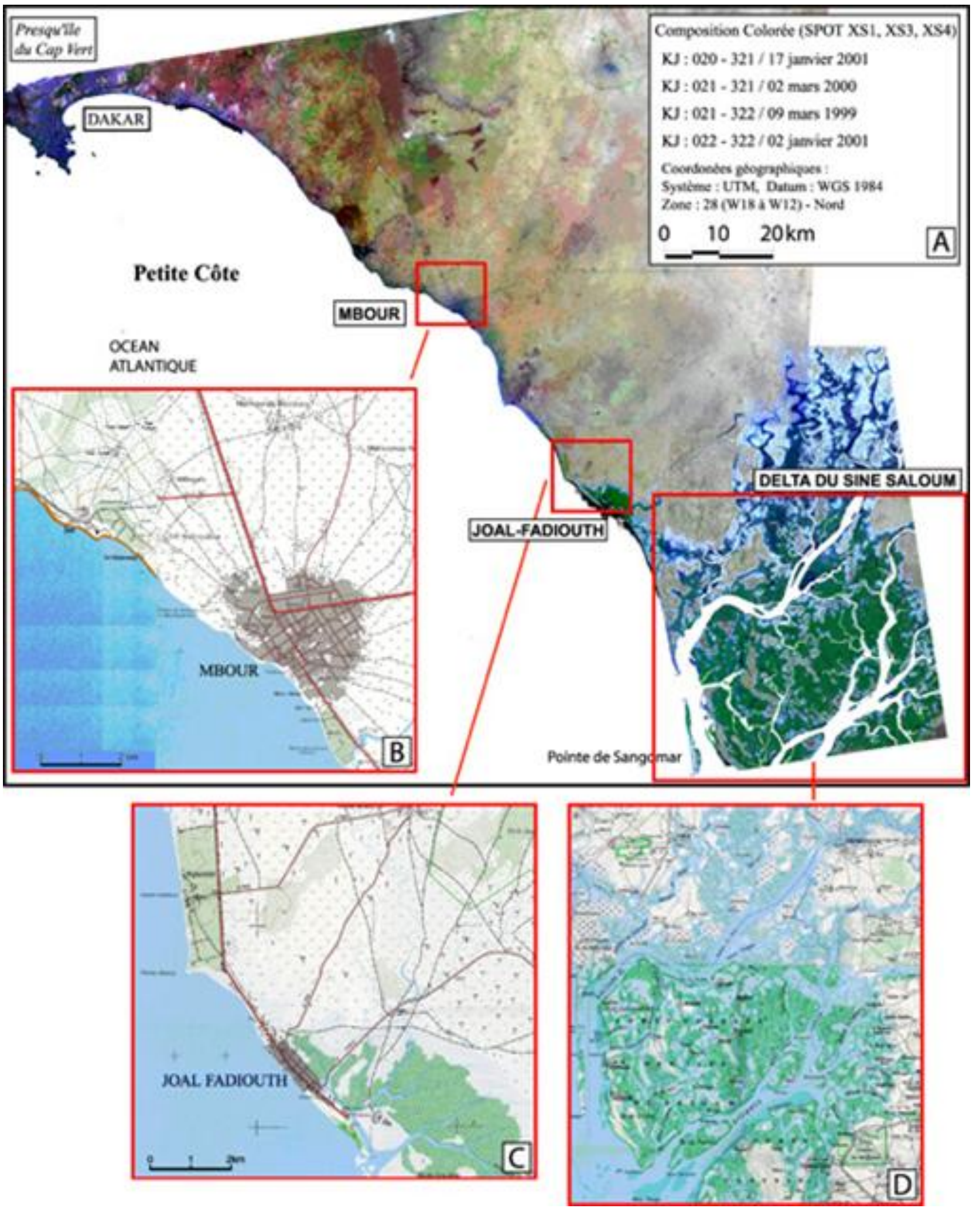

Figure 1. Location map of the sampling sites (Source: http://www.vertigo.revues.org/docannexe/image/2206/img-1.jpg) 


\subsection{Sampling Strategy}

Sampling was realized in large centers landings of Mbour and Joal (sea) and Sine-Saloum (estuary). The samples were collected monthly from March 2012 to February 2013 and from catches of commercial scale fishing. We did not get samples at Mbour and Joal (sea) in April and October 2012 because there was no landing of Ethmalosa fimbriata. Sampled fish were and measured with a graduated rule and weighed with an electronic balance. In total, 1197 fish of which 547 at sea and 650 in estuary were measured and weighted. The variables studied are the total length $(\mathrm{Lt})$, the fork length $(\mathrm{Lf})$, standard length $(\mathrm{Ls})$ : total weight $(\mathrm{Pt})$, eviscerated weight (Pev), gonad weight $(\mathrm{Pg})$.

\subsection{Study of Reproduction}

The sex ratio is defined as the proportion of male or female individuals in relation to the total workforce. It gives an idea about the gender balance within the population. The sex ratio is expressed in this study as a percentage of males and calculated according to the following formula (Layachi et al 2007):

$$
S R=M \times 100 \times \frac{1}{(M+F)}
$$

Where $\mathrm{SR}=$ Sex ratio, $\mathrm{F}=$ female and $\mathrm{M}=$ male .

The size at first sexual maturity (L50) is the length at which $50 \%$ of fish are sexually mature (Fontana, 1969; Conand, 1976). The percentage of size class (1 cm intervals) females or males which have reached stage III was calculated relatively to the total number of sexually mature females or males during the spawning period. A logistic function between the percentages of mature fish and the average length of the interval (Ghorbel et al. 1996) was used. This function is written:

$$
\% M=\frac{100}{1+e^{-a\left(L f-L_{50}\right)}}
$$

Where $\% \mathrm{M}$ is the percentage of mature fish by size class; L50: the size at first sexual maturity Lf: center class fork length, a: parameter of the relationship.

Determining the breeding season was realized with changing sexual maturity stages and changes gonadosomatic index (GSI). The percentages of sexual stages relative to the total number of females sampled were calculated. Stages I and II are grouped and considered as immature and from stage III, all individuals are considered mature. Only females were considered for the study of the evolution of sexual maturity stages because their sexual maturity stages are easier to recognize (Fontana, 1969). Gonadosomatic index (GSI) is the percentage of gonad weight relative to eviscerated weight (Bougis, 1952). This ratio is given by the following formula: 


$$
G S I=\frac{P g}{P e v} \times 100
$$

Where Pg: gonad weight and Pev: weight of eviscerated fish.

The absolute fecundity (number of oocytes in the ovary) and relative (number of oocytes per unit of body weight) were estimated in order to determine the reproductive potential. Absolute fecundity (FA) was determined from the number of oocytes present in a fraction of ovarian stage IV or V on the total weight of the gonad. The relative fecundity (FR) is obtained by dividing the absolute fecundity by eviscerated weight. Relative fecundity is used to compare the fertility of fish from diverse backgrounds (Albaret and Dominique, 1982).

Absolute fecundity:

$$
A F=\frac{n \times P g}{P}
$$

Relative fecundity:

$$
R F=\frac{A F}{P e v}
$$

Where $\mathrm{AF}=$ absolute fecundity, $\mathrm{RF}=$ relative fecundity, $\mathrm{n}=$ the number of oocytes in the sample of $0.05 \mathrm{~g} \mathrm{Pg}=$ the ovary weight $(\mathrm{g}), \mathrm{P}=$ weight of sample $(\mathrm{g}), \mathrm{Pev}=$ eviscerated weight (g).

\subsection{Statistical Analysis}

Statistical analysis and graphics were performed with Excel and R. The Student $\mathrm{t}$ test and chi-square test were used to verify the significance of certain results.

\section{Results}

\subsection{Sex Ratio}

The observations made on different samples from the estuary and the sea led to the gender distribution of Ethmalosa fimbriata. This species exhibits a sex ratio slightly in favor of females $(54 \%)$ compared to males $(46 \%)$ in the estuary. However, at sea, the percentage of females $(58 \%)$ is slightly higher than that of males (42\%). The sex ratio by size class in the estuary indicates that males are more numerous in the smaller sizes (Figure 2). Beyond $20 \mathrm{~cm}$, females are becoming more numerous in the samples up to 100\% (Figure 2). At Sea, beyond 18 $\mathrm{cm}$ the sex ratio per size class is in favor of females (Figure 3). 


\section{Macrothink $\Lambda$ Institute"}

$\square$ Female $\square$ Male

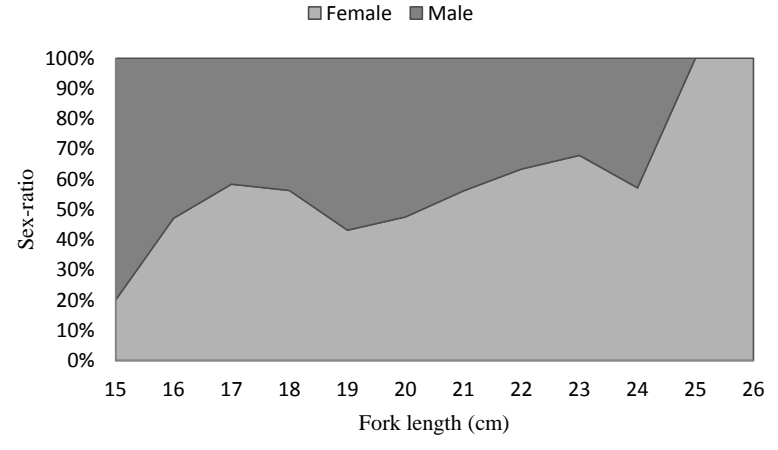

Figure 2. Sex ratio by size class of Ethmalosa fimbriata in estuary
Journal of Biology and Life Science

ISSN 2157-6076

2014, Vol. 5, No. 1

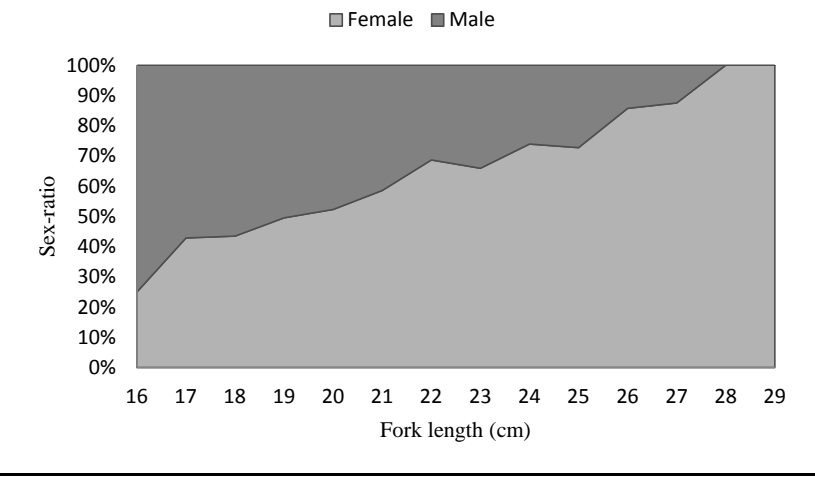

Figure 3. Sex ratio by size class of Ethmalosa fimbriata at sea

\subsection{Sexual Maturity}

The size at first maturity, size at which $50 \%$ of individuals are mature (L50) is $16.20 \mathrm{~cm}$ for males and $17.50 \mathrm{~cm}$ for females in the estuary (Figure. 4). The difference in size at first maturity between the sexes was significant $(p<0.05)$. The L50 values found at sea (Figure 5) for females $(18.70 \mathrm{~cm})$ and males $(17.20 \mathrm{~cm})$ were significantly different $(\mathrm{p}<0.05)$.

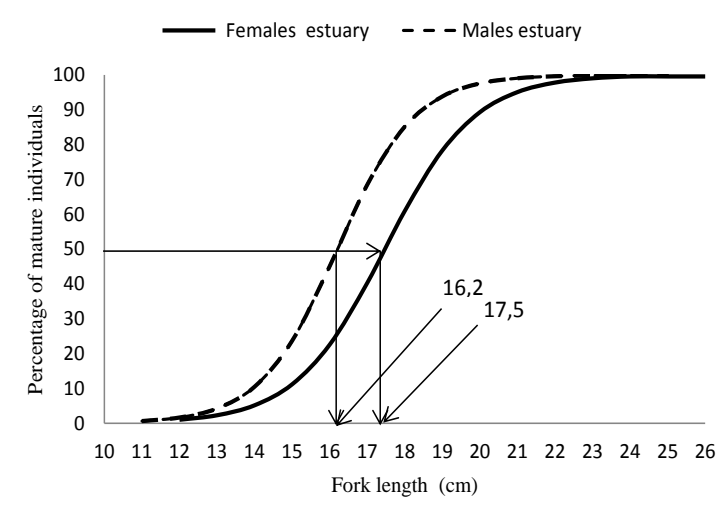

Figure 4. Size at first sexual maturity of males and females Ethmalosa fimbriata in estuary

\subsection{Periods of Reproduction}

\subsubsection{Evolution of Sexual Maturity Stages}

These figures 6 and 7 showed the evolution of sexual maturity stages of females in estuary and at sea. The stages of pre-spawning and spawning (IV and V) are more represented in the cold season (November to May) in estuary. But at sea these stages are more frequent in the hot season (June to October). For now, we can assume the reproduction occurred during the cold season in the estuary and in the hot season at sea. 


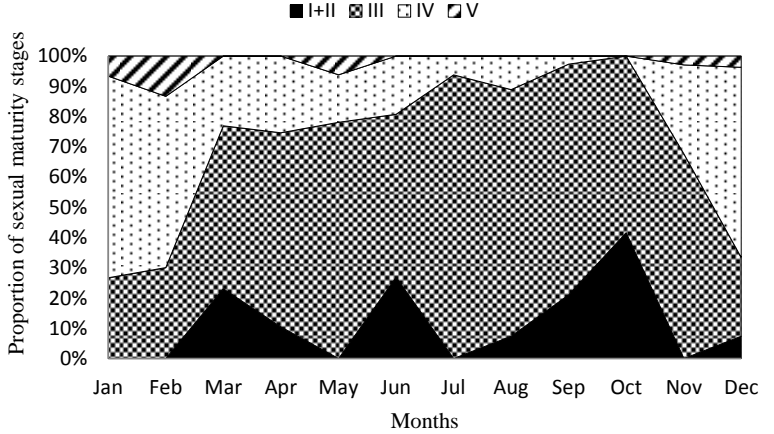

Figure 6. Evolution of the stages of sexual maturity of female Ethmalosa fimbriata in estuary

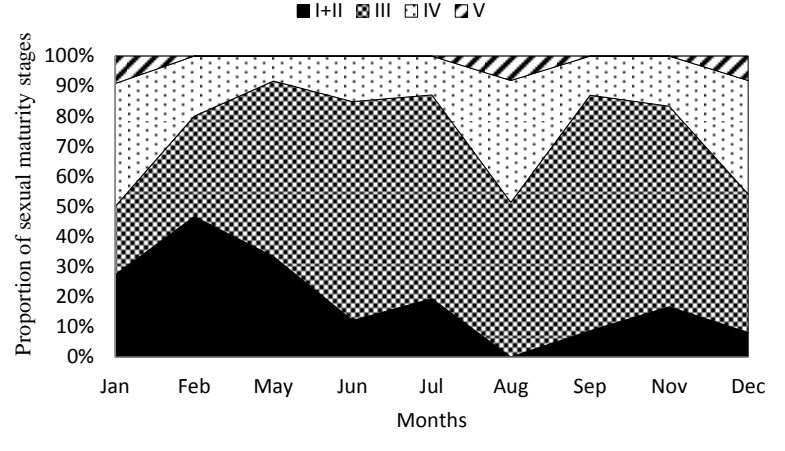

Figure 7. Evolution of the stages of sexual maturity of female Ethmalosa fimbriata at sea

\subsubsection{Gonadosomatic Index (GSI)}

In estuary, spawning covers a long period of the year (Figure 8). However, it is more intense from January to June (cold season) with a single peak in April (4.27). The GSI is significantly higher in the estuary during the cold season $(\mathrm{p}<0.05)$. Figure 9 shows that the reproduction is spread throughout the year at sea. But, sexual activity of Ethmalosa fimbriata is significantly greater during the hot season $(\mathrm{p}<0.05)$. The maximum period of gonadal maturation was observed in August (5.57).

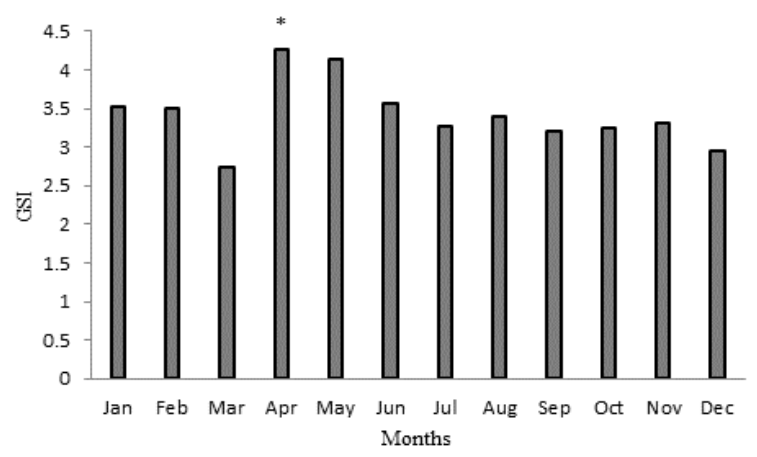

Figure 8. Monthly gonadosomatic index (GSI) of Ethmalosa fimbriata estuary

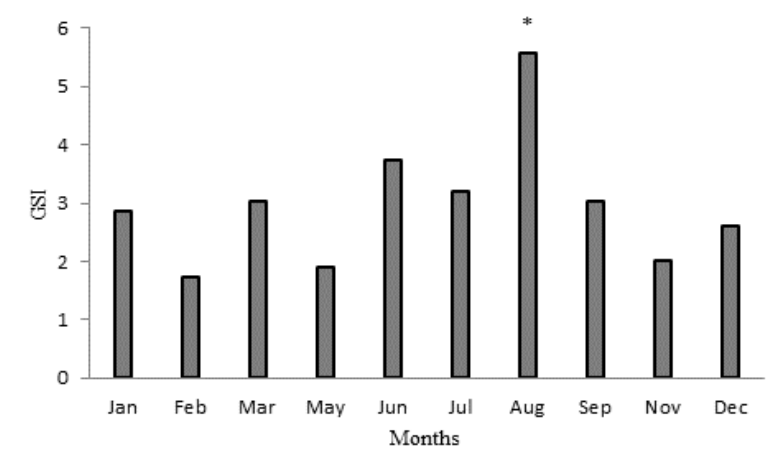

Figure 9. Monthly gonadosomatic index (GSI) of Ethmalosa fimbriata at sea

\subsection{Fecundity}

At sea, absolute fecundity and relative fecundity are respectively equal to 50694 and 257 eggs per gram of female. However, in estuary, the two fecundities are respectively equal to 51083 eggs and 317 eggs per gram of female. Ethmalosa fimbriata has a very high fecundity. The difference between absolute fecundity at sea and estuary is not significant $(p>0.05)$. However, the relative fecundities in both environments are significantly different $(\mathrm{p}<0.05)$. 


\section{Discussion}

\subsection{Sex Ratio}

In estuary, the sex ratio expressed as a percentage of male is equal to $46 \%$ while at sea it is $42 \%$. These results are in agreement with those of Gerlotto (1979) in Côte d'Ivoire; Scheffers et al. (1976) in The Gambia; Fagade and Olanyan (1972 ) in Nigeria and Olsen and Lefevere (1966) in Nigeria . However, the results of Boely et al. (1979) and Scheffers et al. (1972) in Senegal; Olsen and Lefevre (1966) in the Niger Delta, as well as those of Salzen (1958) in Sierra Leone, showed a sex ratio in favor of males. The sex ratio in favor of females could be due to factors such as the movement for search of food and growth differential between the two sexes (Panfili et al. 2004). Indeed, the sex ratio often reflects the adjustment mechanisms in food availability (which is also depending on the density). In Clupeidae, the number of females is slightly often higher than males (Boely et al. 1979). The predominance of females in large sizes during breeding periods would be due to a greater vulnerability during this period. The effect of fishing gear may be one of the causes. Females being larger than males in large classes generally, they may be more vulnerable to a given mesh (Gerlotto 1979). The hypothesis of a higher natural mortality for males is not to exclude (Caverivière, 1982).

Table 1. Sex ratios Ethmalosa fimbriata percentage of male according to various authors

\begin{tabular}{|c|c|c|c|}
\hline Countries & Sex-ratio & Number of individuals & Authors \\
\hline Estury (Senegal) & $46 \%$ & 650 & \multirow{2}{*}{ Present study } \\
\hline Sea (Sengal) & $42 \%$ & 547 & \\
\hline Senegal & $50 \%$ & 667 & Boely and Elwertowski (1979) \\
\hline Senegal & $50 \%$ & 3259 & Scheffers et al. (1972) \\
\hline Gambia & $29 \%$ & 2337 & Scheffers and Conand (1976) \\
\hline Gambia & $45 \%$ & 13962 & Scheffers and Conand (1976) \\
\hline Ivory Coast & $35 \%$ & 852 & Gerlotto (1979) \\
\hline Sierra Leone & $54 \%$ & 2265 & Salzen (1958) \\
\hline Nigeria & $47 \%$ & 348 & Fagade and Olanyan (1972) \\
\hline Niger & $63 \%$ & - & Olsen andLefevere (1966) \\
\hline
\end{tabular}

\subsection{Sexual Maturity}

The analysis of fish during the breeding season, indicate that $50 \%$ of females are mature from $18.7 \mathrm{~cm}$ at sea and $17.5 \mathrm{~cm}$ in estuary. This percentage is reached from $16.2 \mathrm{~cm}$ for males in estuary and $17.2 \mathrm{~cm}$ at sea. Size at first sexual maturity depends on the growth of individuals. These differences in size are associated with gender differences related to the relative distribution of energy in the production of gametes (Weatherley and Gill, 1987). Males reach sexual maturity earlier than females. Indeed, males mature and grow and die rather less rapidly than females (Al -Hakim et al. 1980). The size differences observed between the same sexes of the two areas would be due to the difference of the two living environments. Thus, for the same species living in different environments, growth and size at first sexual maturity can also be very different (Wague and M'Bodj, 2002). More generally, the reduction in the size of maturity for different species may reflect an adaptive response to overexploitation (Smith 1994). The 
size of sexually mature fish may be related to adult mortality. In a population where adult mortality is too high, the fish breed in a very young size. Fishing of Ethmalosa fimbriata is more intense at the Saloum estuary than the sea (DPM, 2010), this can be one of the causes of this difference in size at first maturity between these two environments. These results corroborated with those reported for the same species by Scheffers et al (1972) in Senegal, Scheffers (1976) Gambia, Salzen (1958) Sierra Leone (Table 2). The works of Albaret and Dominique (1982) and Albaret and Gerlotto (1976) in Ivory Coast, and Fagade Olanyan (1972) in Nigeria and N'goran (1991) Ivory Coast showed that males reach sexual maturity first. However, the sizes at first maturity are low for both sexes.

Table 2. The sizes at first sexual maturity observed for Ethmalosa fimbriata in different countries

\begin{tabular}{|c|c|c|c|}
\hline \multirow{2}{*}{ Countries } & \multicolumn{2}{|l|}{ Size at first sexual maturity (L50) } & \multirow{2}{*}{ Authors } \\
\cline { 2 - 3 } & Male & Female & \multirow{2}{*}{ Present study } \\
\hline Estuary Senegal & L50 $=16.2 \mathrm{~cm}$ & L50 $=17.5 \mathrm{~cm}$ & \multirow{2}{*}{ Panfili et al. (2004) } \\
\hline Sea (Senegal) & L50 $=17.2 \mathrm{~cm}$ & L50 $=18.7 \mathrm{~cm}$ & Diouf (1996) \\
\hline Gambia & L50 $=20.2 \mathrm{~cm}$ & L50 $=19.1 \mathrm{~cm}$ & Scheffers et al. (1972) \\
\hline Senegal & L50 $=17.3 \mathrm{~cm}$ & L50 $=15.3 \mathrm{~cm}$ & Scheffers (1976) \\
\hline Senegal & L50 $=17.5 \mathrm{~cm}$ & L50 $=18 \mathrm{~cm}$ & Salzen (1958) \\
\hline Senegal & L50 $=16 \mathrm{~cm}$ & L50 $=17 \mathrm{~cm}$ & Albaret and Gerlotto (1976) \\
\hline Gambia & - & L50 $=18.5 \mathrm{~cm}$ & Albaret and Charles- Dominique (1982) \\
\hline Sierra Leone & \multicolumn{2}{|c}{ L50 : $20 \mathrm{~cm}$} & Fagade and Olanyan (1972) \\
\hline Ivory Coast & L50 $=13 \mathrm{~cm}$ & L50 $=14 \mathrm{~cm}$ & \\
\hline Ivory Coast & L50 $=8.1 \mathrm{~cm}$ & L50 $=8.4 \mathrm{~cm}$ & Alan \\
\hline Nigeria & L50 $=10 \mathrm{~cm}$ & L50 $=14 \mathrm{~cm}$ & \\
\hline
\end{tabular}

\subsection{Reproduction Periods}

\subsubsection{Evolution of Sexual Maturity Stages}

In summary, the percentage of mature females is much more important during the cold season in the estuary while at sea this percentage is higher in the hot season. This suggests that the reproduction of Ethmalos a fimbriata at sea is in the hot season. The rate of mature females significantly higher than that of immature females in the estuary during the cold season is confirmed by the works of Albaret et al. (2005). They show that in the dry season, adults and juveniles are present in the estuary with more breeding adults, whereas at the end of the rainy season, there are essentially so many juveniles. This shows that the major spawning period in the estuary is at cold season. The evolution of sexual maturity stages of Ethmalosa fimbriata has not been the subject of many studies. Scheffers et al. (1972), contrary to our results; showed a predominance of immature during the period from September to November, while December to June the mature females are superior.

\subsubsection{Gonadsomatic Index (GSI)}

The maximum value of GSI in estuary is recorded in April (4.27), while in the sea, GSI is 
higher in August (5.57). Thus, the maximum spawning in the estuary is the cold season, while at sea this maximum is observed in the hot season. These results are confirmed by the evolution of the different stages of sexual maturity. In estuary, the results found in this study are similar to those of Albaret and Gerlotto (1979) in Ivory Coast; Fagade and Olanyan (1972) in Nigeria; N'goran (1991) Ivory Coast and Panfili et al. (2004). The results found in the sea are consistent with those of Salzen (1958) and Bainbridge (1961). Seasonal difference of the reproduction observed between Ethmalosa fimbriata at sea and those of the estuary could be due to the fact that breeding of Ethmalosa fimbriata is related to salinity (Scheffers et al. 1972). Some environmental parameters such as salinity affect reproduction (Charles -Dominique, 1982). Indeed, the salinity is higher in the estuary of Saloum in the cold season (after the rainy season) with a maximum from May to April (Panfili et al. 2004). Thus, changes in the GSI combined with the evolution stages of sexual maturity can locate the main breeding periods January to June estuary and January-February and July-September at sea.

Table 3. Period reproduction Ethmalosa fimbriata in Senegal and elsewhere

\begin{tabular}{|c|c|c|c|c|c|c|c|c|c|c|c|c|c|}
\hline \multirow{2}{*}{ Countries } & \multicolumn{7}{|c|}{ Reproduction Periods } & \multirow{2}{*}{ Authors } \\
\hline & J & F & M & A & M & J & J & A & S & O & N & D & Present study \\
\hline Sea (Senegal) & & & & & & & & & & & & & \\
\hline Estuary (Senegal) & & & & & & & & & & & & & Panfili et al. (2004) \\
\hline Senegal and Gambia & & & & & & & & & & & & & N'goran (1991) \\
\hline Ivory Coast & & & & & & & & & & & & & Scheffers et al. (1972) \\
\hline Senegal and Gambia & & & & & & & & & & & & & Albaret and Gerlotto (1976) \\
\hline Ivory Coast & & & & & & & & & & & & & \\
\hline Sierra Leone & & & & & & & & & & & & & Salzen (1958) and Bainbridge (1961) \\
\hline Nigeria & & & & & & & & & & & & & Fagade and Olanyan (1972) \\
\hline
\end{tabular}

\subsection{Fecundity}

At sea, the absolute and relative fecundity found in this study are equal to 50694 and 257 eggs per gram of female. In Estuary, both fecundities are respectively equal to 51083 and 317 eggs per gram of female. These results are similar to those of Albaret and Gerlotto (1976) in Côte d'Ivoire. These authors showed that the relative fecundity of Ethmalosa fimbriata is between 150 to 300 eggs per gram of female. However, the values of relative fecundity found in this study are different with those of Panfili et al. (2004) in the Saloum estuary (150 oocytes) and Gambia (110 oocytes) and those of Fagade (1974) Nigeria (500 oocytes). The differences in relative fecundity observed between the sea and the estuary may be due to several factors. In estuarine and lagoon environments, a reproductive strategy aims on the one hand to limit the negative effects of the instability of the environment and on the other hand to fight against the spread of eggs, larvae and embryos outside the estuary. Thus, the oviparous develop two tactics. The first tactic is based on maximizing the number of eggs made and it has the effect of increasing the likelihood that at least a fraction of the population can be transported in a favorable place to ensure recruitment (example: Ethmalosa fimbriata). The second attempts to maximize the survival of eggs, larvae by limiting the number of eggs issued and using parental care (Sarotherodon) (Dadzie et al. 2008). Thus, it can be assumed that depending on 
environmental conditions, fecundity acts as a regulator of the survival of the species.

\section{Conclusion}

This work has highlighted the sex ratio of Ethmalosa fimbriata in the estuary and at sea. Sizes at first sexual maturity in the estuary and at sea were also determined. Reproduction periods are determined by studying the evolution of the different stages of sexual maturity, and changes of gonadosomatic index (GSI). The absolute and relative fecundities in the estuary and at sea were estimated. The application of these results may help treat certain problems of population dynamics, thus helping to management stock. Indeed, knowledge of the size at first sexual maturity informs on the fraction of the stock that is capable of ensuring the renewal of the species and therefore it provides information about the minimum legal size of fish that can be caught. From the reproduction periods determined, possible biological rest can be made. This work helped to provide some understanding of the reproduction of Ethmalosa fimbriata living at sea and in the Saloum estuary. In the future, this work deserves to be continued to define migration of Ethmalosa fimbriata which exist between the estuary and the sea that are hitherto poorly understood.

\section{Acknowledgements}

The study was realized within the framework of the USAID/COMFISH project. This project funded by USAID was implemented by the University of Rhode Island in the United States and Senegalese partners including University Institute of Fisheries and Aquaculture. We would like to acknowledge the Director of USAID/COMFISH Chris Mathews and all other members, particularly Khady Sane DIOUF and Dr. Vaque NDIAYE for their suggestions, their support and encouragement. We are also very grateful to Omar SADIO (IRD) for the statistical analysis.

\section{Reference}

Albaret, J. J., \& Gerlotto, F. (1976). Biologie de l'ethmalose (Ethmalosa fimbriata Bowdich) en Côte d'Ivoire. Description de la reproduction et des premiers stades larvaires. Doc. Sci. Cent. Rech. Océanogr.d'Abidjan, 1(7), 113-133.

Albaret, J. J. Charles-Dominique E. (1982). Observation d'une taille à la première maturation sexuelle exceptionnellement faible chez (Ethmalosa fimbriata Bowdich) dans une baie polluée de la lagune Ebrie (Cote d'Ivoire). Doc. Sci. Cent. Rech. Océanogr.d'Abidjan, ORSTOM, 8(2), 23-31.

Albaret, J. J., Simier, M., \& Sadio, O. (2005). Suivi biologique des peuplements de poissons d'une aire protégée en zone de mangrove : le bolon de Bamboung (Sine Saloum, Sénégal). Rapport final. Rapport de convention Narou Heuleuk/AFD/IRD, 80p.

Bainbridge, V. (1961). The early life history of the bonga, Ethmalosa dorsalis (Cuvier and Valenciennes). Journal du Conseil International pour l'Exploration de la Mer, 28(3), 347-353. http://dx.doi.org/10.1093/icesjms/26.3.347

Blanc, A. (1951). La pêche du cobo (Ethmalosa fimbriata) sur la petite côte du Sénégal. Bull. 
Serv. Elev. Ind. Anim., AOF, 4(4), 31-38.

Boely, T., \& Elwertowski, J. (1970). Observations préliminaires sur la pêche de Ethmalosa fimbriata (Bowdich) des eaux sénégalaises et son aspect biologique. Rapp. P.V. Réun. CIEM, 1959, 182-188.

Boely, T., \& Freon, P. (1979). Les ressources pélagiques côtières. Doc. Sci. Provis. Cent. Rech. Océanogr. Dakar-Thiaroye. ORSTOM. 66p.

Bougis, P. (1952). Recherches biométriques sur les rougets Mullus barbatus L., et Mullus surmuletus L., Arch. Zool. exp. et gén., 89(2), 57-174.

Caverivière, A. (1982). Exploitation des espèces capturées par les chalutiers sur le plateau continental ivoirien. Modèles analytiques et conséquences en matière d'aménagement. Doc. Sci. Cent. Rech. Océanogr.d'Abidjan, 1(13), 1-51.

Charles-Dominique, E. (1982). Exposé synoptique des données biologiques sur l'ethmalose (Ethmalosa fimbriata Bowdich, 1825). Rev. Hydrobio. Trop., 15(4), 373-397.

Conand, C. (1976). Contribution à l'étude du cycle sexuel et de la fécondité de la sardinelle ronde, Sardinella aurita: Pêche sardinière dakaroise en 1975 et premier semestre 1976. Cahiers ORSTOM, Série Océanographique, 1977(4), 301-312.

Dadzie, S., \& Abou-Seedo, F. (2008). Reproductive guids (maturation, spawning frequency and fecundity) in the black pomfret, Parastromateus niger (Carangidae) in the Kuwaiti waters of the Arabian Gulf. J. Appl. Ichthyol., 24, 1-7. http://dx.doi.org/10.1111/j.1439-0426.2008.01074.x

Diouf, P. S. (1996). Les peuplements de poissons des milieux estuariens de l'Afrique de l'Ouest: L'exemple de l'estuaire hyperhalin du Sine-Saloum. Thèse de doctorat, Université de Montpellier II, 267p.

DPM. (2010). Direction des Pêches Maritime. Résultats généraux de la pêche maritime sénégalaise, $104 \mathrm{p}$.

Fagade, S. O. (1974). Age determination in Tilapia melanotheron (Ruppel) in the Lagos lagoon, Nigeria. In: Proceeding of the symposium on ageeing of fish, Urwin. Broth. Ltd. Edit., Lond., 71-77.

Fagade, S. O., Olaniyan, C. I. O. (1972). The biology of the West African shad Ethmalosa fimbriata (Bodwich) in the Lagos Lagoon, Nigeria. J. Fish. Biol., 4(4), 519-533. http://dx.doi.org/10.1111/j.1095-8649.1972.tb05699.x

FAO. (2005). L'état des ressources halieutiques marines mondiales. Service des ressources marines, Division des ressources halieutiques, département des pêches de la FAO. FAO Document technique sur les pêches, 457, 23p.

FAO. (2009). Report of the FAO Working Group on the Assessment of Small Pelagic Fish off Northwest Africa. Nouakchott, Mauritania, 21-31 April 2009. FAO Fisheries Report, Rome, 2008, 849, 238p. 
FAO. (2010). The state of world fisheries and aquaculture. Rome, Italy, FAO. 197p.

FAO. (2011). Report of the FAO Working Group on the Assessment of Small Pelagic Fish of Northwest Africa. Banjul, the Gambia, 18-22 may 2010. FAO Fisheries and Aquaculture, Rome, 2011, 975, 263p.

Fontana, A. (1969). Etude de la maturité sexuelle des sardinelles, Sardinella eba (Val.) et Sardinella aurita (C et V.) de la région de Pointe-Noire. Cahiers ORSTOM Série Océanographie, 7(2), 101-114.

Gerlotto F. (1979). Biologie de Ethmalosa fimbriata (Bowdich) en Côte d'Ivoire. III. Etude des migrations en lagune Ebrié. Doc. Sci. Cent. Rech. Océanogr.d'Abidjan, ORSTOM, 10(2), 3-41.

Gerlotto, F. (1976). Biologie de Ethmalosa fimbriata (Bodwich) en Côte d'Ivoire. II. Etude de la croissance en lagune par la méthode de Petersen. Document Scientifique du Centre de Recherches Océanographique d'Abidjan, 7(2), 1-27.

Ghorbel, M., Jarboui, O., Bradai, M. N., \& Bouain, A. (1996). Détermination de la taille de première maturité sexuelle par une fonction logistique chez Limanda limanda, Pagellus erythrinus et Scorpaena porcus. Bull. INSTM, n. spec., 3, 24-27.

Layachi, M., Melhaoui, M., Srour, A., \& Ramdani, M. (2007). Contribution à l'étude de la reproduction et de la croissance du Rouget-barbet de vase (Mullus barbatus L., 1758) de la zone littorale méditerranéenne de Nador (Maroc). Bulletin de l'Institut Scientifique, Rabat, section Sciences de la Vie, 29, 43-51.

N'goran, Y. N. (1991). Reproduction de Ethmalosa fimbriata en lagune ABY (Cote d' Ivoire). (Côte d'ivoire). Jour. Ivoir. Océanol. Limnol. Abidjan, 1(1), 23-32.

Olsen, S., \& Lefevre, S. (1966). Some observations on length and sex distributions and catch effort on Bonga Ethmalosa fimbriata (Bowdich). In: Actes du symposium sur l'océanographie et les ressources halieutiques de l'atlantique tropicale, 23, 277-280

Panfili, J., Durand, J. D., Mbow, A., Guinand, B., Diop, K., Kantoussan, J., Diaga, T., Thiaw, O. T., Albaret, J. J., \& Lae, R. (2004). Influence of salinity on life history traits of the bonga shad Ethmalosa fimbriata (Pisces, Clupeidae): Comparison between the Gambia and Saloum estuaries. Marine Ecology Progress Series., 270, 241-257. http://dx.doi.org/10.3354/meps270241

Rapport de Groupe de Travail sur l'évaluation des stocks petits pélagiques dans la région Nord Ouest Africaine (COPACE). (2012)

Salzen, E. A. (1958). Observations on the biology of african shad, Ethmalosa fimbriata (Bowdich). Bulletin de l'Institut Français d'Afrique Noire, Série A, 20(4), 1388-1426.

Scheffers, W. J. (1973). Etude de Ethmalosa fimbriata (Bowdich) dans la region sénégambienne. $2^{\mathrm{e}}$ note: la pêche et le stock de Ethmalosa fimbriata dans le fleuve Sénégal et la région de Saint-Louis. Doc. Sci. Provis. Cent. Rech. Océanogr. Dakar-Thiaroye, ORSTOM, 
$45,33 \mathrm{p}$.

Scheffers, W. J., \& Conand, F. (1976). A study on Ethmalosa fimbriata (Bowdich) in the senegambian region. III. - The biology of the Ethmalosa in Gambian waters. Doc.Sci.Provis. Cent. Rech. Océanogr. Dakar-Thiaroye, 59, 1-19.

Scheffers, W. J., Conand, F., \& Reizer, C. (1972). .Etude de Ethmalosa fimbriata (Bowdich) dans la région sénégambienne. $1^{\text {ére }}$ note: Reproduction et lieux de ponte dans le fleuve Sénégal et la région de Saint-Louis. Doc. Sci. Provis. Cent. Rech. Océanogr. Dakar-Thiaroye, ORSTOM, 44, 21p.

Smith, P. J. (1994). Genetic diversity of marine fisheries resources: possible impacts of fishing. FAO Fish. Tech. Pap., 344, 55p.

Wague, A., \& M'Bodj, O. B. (2002). Etude de quelques aspects de la reproduction chez la sardinelle ronde Sardinella aurita (Valenciennes, 1847) péchée le long des côtes mauritaniennes. Bulletin Scientifique de l'Institut Mauritanien de Recherches Océanographiques et des Pêches, 29, 13-18.

Weatherley, A. H., \& Gill, H. S. (1987). The biology of fish growth. London: Academic Press, 420p.

\section{Copyright Disclaimer}

Copyright reserved by the author(s).

This article is an open-access article distributed under the terms and conditions of the Creative Commons Attribution license (http://creativecommons.org/licenses/by/3.0/). 